\title{
PROXIMATE COMPOSITION AND TECHNOLOGICAL CHARACTERISTICS OF DRY PASTA INCORPORATED WITH MICRONIZED CORN PERICARP ${ }^{1}$
}

\author{
JOÃO RENATO DE JESUS JUNQUEIRA²*, FAUSTO ALVES DE LIMA JUNIOR ${ }^{2}$, GISELE SOUZA FERNANDES ${ }^{2}$, \\ MARIA CRISTINA DIAS PAES ${ }^{3}$, JOELMA PEREIRA ${ }^{2}$
}

\begin{abstract}
Pastas are generally accepted all over the world, mainly because they are versatile, cheap and easy-to-prepare. They are not nutritionally balanced, since they provide mainly carbohydrates. As a result of this, it is important to use ingredients which could improve the nutritional deficiencies, without affecting the technological and sensorial characteristics. This study evaluated the effect of using wheat semolina and micronized corn pericarp (MCP), on the proximate composition, cooking quality and color of spaghetti type pasta. Spaghetti pasta was produced using wheat semolina with the incorporation of micronized corn pericarp, at levels of $0,10,20$ and 30\%. There were no significant differences $(p>0.05)$ between the formulated samples with regards to the contents of moisture and lipid, cooking time, weight gain and volume increase. As observed, supplementation with micronized corn pericarp presented significant difference on the contents of proteins, minerals, dietary fiber and solid soluble loss of the spaghetti pasta $(p<0.05)$. With increase in micronized corn pericarp concentration, the color difference became accentuated. The use of MCP appears to be viable, providing a nutritionally enriched product without further impairment on pasta quality.
\end{abstract}

Keywords: Fiber. Pasta. Micronized pericarp. Wheat semolina. Corn.

\section{COMPOSIÇÃO E CARACTERÍSTICAS TECNOLÓGICAS DE MASSA ALIMENTÍCIA SECA INCORPORADA DE PERICARPO MICRONIZADO DE MILHO}

\begin{abstract}
RESUMO - Massas alimentícias apresentam boa aceitação em todo o mundo, principalmente devido à sua versatilidade, baixo preço e facilidade de preparo, porém, não são nutricionalmente equilibradas fornecendo basicamente carboidratos. Assim sendo, o uso de ingredientes alternativos que reduzam as essas deficiências nutricionais, sem afetar, no entanto, suas características tecnológicas e sensoriais. Este trabalho avaliou o efeito da utilização de semolina de trigo e pericarpo micronizado de milho (PMM) na composição físico-química, qualidade de cozimento e cor de massas tipo espaguete. Espaguete foi produzido utilizando farinha de trigo, com a incorporação de pericarpo de milho, nas concentrações de 0, 10, 20 e 30\%. Não foram observadas diferenças no conteúdo de umidade e lipídios, tempo de cozimento, ganho de peso e aumento de volume $(\mathrm{p}>0,05)$. Foi possível observar que a suplementação com pericarpo micronizado de milho apresentou diferença significativa no conteúdo de proteínas, minerais, fibras alimentares e perda de sólidos solúveis dos espaguetes $(\mathrm{p}<0,05)$. Com o aumento da concentração de pericarpo micronizado de milho, a diferença de cor foi acentuada. A utilização de PMM mostrou-se viável, apresentando um produto enriquecido nutricionalmente sem maiores comprometimentos à qualidade final das massas.
\end{abstract}

Palavras-chave: Fibra. Massa alimentícia. Pericarpo micronizado. Semolina de trigo. Milho.

\footnotetext{
*Corresponding author

${ }^{1}$ Received for publication in 10/28/2014; accepted in 09/28/2016.

Paper extracted from the monograph of the first author.

${ }^{2}$ Department of Food Science, Universidade Federal de Lavras, Lavras, MG, Brazil; jrenatojesus@hotmail.com, fjuniorea@gmail.com, gisofe@yahoo.com.br, joper@dca.ufla.br.

${ }^{3}$ Empresa Brasileira de Pesquisa Agropecuária Milho e Sorgo, Sete Lagoas, MG, Brazil; cristina.paes@embrapa.br.
} 


\section{INTRODUCTION}

The demand for a balanced diet, with all required nutrients, combined with the convenience and quickness, has increased. In this context, foods which present health benefits, such as functional properties, with incorporation of nutrients and reduced caloric values are notable.

Pastas are made with flour and water and may contain egg (IBITOYE et al., 2013). It is an easy-to-prepare food, versatile, cheap and commonly consumed around the world, especially by the poor. It is an energetic food, which presents deficiencies regarding nutritional value and quality of protein and low fiber content, since they are mainly produced with wheat flour (SUN-WATERHOUSE; JIN; WATERHOUSE, 2013; SIRICHOKWORRAKIT; PHETKHUT; KHOMMOON, 2015).

In 2015, Brazil exported approximately 1.312 tons of dry pastas with eggs. The United States and Portugal are the countries with the largest volume of exportation. This year, the consumption of pastas in Brazil has reached $4.35 \mathrm{~kg} /$ per capita (ABIMAPI, 2016). Several researchers have studied the supplementation of the nutritional properties of pastas (ROCHA et al., 2008; GALLEGOS-INFANTE et al., 2010; KAUR et al., 2012; SUN-WATERHOUSE; JIN; WATERHOUSE, 2013; SIRICHOKWORRAKIT; PHETKHUT; KHOMMOON, 2015). In general, the studies concluded that the inclusion of different ingredients could improve the nutritional value of pastas.

The Food and Agricultural Organization (FAO) defines dietary fiber as substances with animal or vegetal origin, resistant to enzymatic hydrolysis in the gastrointestinal system. The American Dietetic Association recommends the ingestion of 25 to $30 \mathrm{~g}$ of fiber per adult/day or 10 to $13 \mathrm{~g} / 1000 \mathrm{Kcal}$ (WHO, 2003). Adequate fiber consumption in a diet reduces the risk of developing some chronic diseases such as cerebrovascular accident (CVA), arterial hypertension, diabetes and gastrointestinal disorders

(BERNAUD;
RODRIGUES, 2013).

Corn grain is basically composed of endosperm, germ and pericarp. These structures differ due to the chemical composition. The pericarp is the structure that protects the other parts from external influence (climate, microorganisms and insects). The cell layers that compose this fraction, basically consist of hemicellulose (67\%) and cellulose $(23 \%)$. The pericarp represents approximately $5 \%$ of the total corn grain and its composition presents about $54 \%$ of the total dietary fiber content in the grain (PAES, 2006). The micronization process is based on the reduction of particles, which contributes to increase in particle solubility/bioavailability. In this context, this study evaluated the effect of using wheat semolina and micronized corn pericarp on the proximate composition, cooking quality and color of spaghetti type pasta.

\section{MATERIAL AND METHODS}

\section{Raw material and composition of pasta}

Wheat semolina, integral dehydrated egg (ASA, Nepomuceno, Brazil), water and micronized corn pericarp (MCP) were used to prepare the spaghetti type pasta. The MCP was utilized in the proportions of $0,10,20$ and $30 \%$ for the spaghetti type pasta preparation of F0 (Control), F10, F20 and F30, respectively (Table 1). The ingredients were mixed in a universal trough (LIEME, AU-300, Brazil) for $15 \mathrm{~min}$. Thereafter, the dough was extruded in a cylinder and molded in wire drawing no. 10 , in wires of approximately $0.30 \mathrm{~m}$, which were extended over nylon screens and dried at an average room temperature of $29.3^{\circ} \mathrm{C}$, and average relative humidity of $57 \%$ for $48 \mathrm{~h}$. The spaghetti type pasta was packed into plastic bags of low density polyethylene, and stored at room temperature for posterior analysis. The experiments were performed in triplicates.

Table 1. Formulation of the spaghetti type pasta from wheat semolina and micronized corn pericarp.

\begin{tabular}{ccccc}
\hline & \multicolumn{3}{c}{ Spaghetti } \\
\cline { 2 - 5 } Ingredients (kg) & F0 & F10 & F20 & F30 \\
\hline & & & & \\
Wheat semolina & 0.500 & 0.500 & 0.500 & 0.500 \\
Dehydrated egg & 0.040 & 0.040 & 0.040 & 0.040 \\
Water & 0.175 & 0.200 & 0.240 & 0.280 \\
MCP & 0.000 & 0.050 & 0.100 & 0.150 \\
\hline
\end{tabular}

The water content was adjusted according to the levels of addition of MCP, to obtain a dough with homogenous consistence.

\section{Product analysis}

Proximate composition
The MCP and spaghetti pastas were subjected to proximate composition (moisture, lipid, ash, protein and dietary fiber) analysis according to AOAC (2010). Carbohydrates were calculated by difference. The proximate composition of MCP was: $2.76 \mathrm{~kg} \quad 100 \mathrm{~kg}^{-1}$ for moisture content, $7.13 \mathrm{~kg} 100 \mathrm{~kg}^{-1}$ for lipid content, $28.14 \mathrm{~kg} 100 \mathrm{~kg}^{-1}$ 
for protein content, $1.37 \mathrm{~kg} 100 \mathrm{~kg}^{-1}$ for ash content, $24.24 \mathrm{~kg} \quad 100 \mathrm{~kg}^{-1}$ for fiber content and $36.36 \mathrm{~kg} 100 \mathrm{~kg}^{-1}$ for carbohydrate content. The caloric value was calculated according to Osborne and Voogt (1978), with the conversion factors: 9 $\mathrm{kcal}$ for lipid g, $4 \mathrm{kcal}$ for protein $\mathrm{g}$ and $4 \mathrm{kcal}$ for carbohydrate $\mathrm{g}$.

\section{Cooking test}

The cooking test was conducted as described by the International Method 66-50 (AACC, 2000).

Approximately, $10 \mathrm{~g}$ of the sample was cooked in $140 \mathrm{~mL}$ of boiling distilled water in a $500 \mathrm{~mL}$ beaker, and the optimum cooking time was evaluated by observing the time of disappearance of the opaque center in the pastas during cooking (every $10 \mathrm{~s}$ ), by squeezing the pastas between two transparent glass slides.

The weight gain is the difference in weight of the cooked and uncooked pastas, which is expressed as the percentage weight of uncooked pastas. Approximately, $10 \mathrm{~g}$ of pasta was weighted before and after cooking, for the ideal cooking time. The analysis indicates the amount of water absorbed by the pasta during the cooking process.

The volume increase was determined before and after the ideal cooking time. The samples were immersed in $140 \mathrm{~mL}$ of hexane before and after the cooking and the volume of hexane displaced was measured.

Soluble solids loss in the cooked pastas were drained and $25 \mathrm{~mL}$ of water was evaporated in an oven at $100^{\circ} \mathrm{C}$ until it reached constant weight. The residue was weighed after cooling in a desiccator to determine soluble solids loss.

\section{Color}

The color of the uncooked pasta samples was determined with a colorimeter (Konica Minolta, CM-5, Japan) equipped with a D65 illuminant using the CIEL ${ }^{*} a^{*} b^{*}$ system. L value is a measure of brightness (0-100); $a^{*}$ represents the red - green coordinates (- is green, while + is red); $b^{*}$ indicates the blue - yellow coordinates (- is blue, while + is yellow). The color differential $(\Delta \mathrm{E})$ between $\mathrm{F} 0$ (pasta with $0 \%$ of MCP) and incorporated spaghetti pasta was calculated as follows (Equation 1):

$$
\Delta \mathrm{E}^{*}=\left[\left(\Delta \mathrm{L}^{*}\right)^{2}+\left(\Delta \mathrm{a}^{*}\right)^{2}+\left(\Delta \mathrm{b}^{*}\right)^{2}\right]^{0.5}
$$

where $\Delta \mathrm{L}^{*}$ is calculated as: $\mathrm{L}_{\text {sample }}^{*}-\mathrm{L}_{\mathrm{F} 0}^{*}$; $\Delta \mathrm{a}^{*}$ is calculated as: $\mathrm{a}^{*}$ sample $-\mathrm{a}_{\mathrm{F} 0}$; and $\Delta \mathrm{b}^{*}$ is calculated as: $\mathrm{b}^{*}$ sample $-\mathrm{b}_{\mathrm{F} 0}$.

\section{Statistical analysis}

Data were subjected to analysis of variance (ANOVA), and the means were compared using Tukey's test at 0.05 significance. A regression test was used when a significant difference $(p<0.05)$ was observed. All the statistics were conducted using the software, Sisvar ${ }^{\circledR} \quad(5.6$ version, Brazil $)$ (FERREIRA, 2014).

\section{RESULTS AND DISCUSSION}

\section{Proximate composition}

For moisture and lipid contents, no statistical difference $(p>0.05)$ was observed between the treatments. The results are presented in Table 2 .

Table 2. Moisture and lipid contents of the spaghetti type pasta from wheat semolina and micronized corn pericarp.

\begin{tabular}{|c|c|c|c|c|}
\hline \multirow[b]{2}{*}{$\begin{array}{l}\text { Chemical } \\
\text { composition } \\
\left(\mathrm{kg} 100 \mathrm{~kg}^{-1}\right)\end{array}$} & \multicolumn{4}{|c|}{ Spaghetti } \\
\hline & F0 & F10 & F20 & F30 \\
\hline Moisture & $11.324 \pm 0.024^{\mathrm{a}}$ & $11.288 \pm 0.018^{\mathrm{a}}$ & $11.314 \pm 0.110^{\mathrm{a}}$ & $11.320 \pm 0.056^{\mathrm{a}}$ \\
\hline Lipid & $2.788 \pm 0.429^{\mathrm{a}}$ & $2.656 \pm 0.371^{\mathrm{a}}$ & $3.061 \pm 0.323^{\mathrm{a}}$ & $2.977 \pm 0.331^{\mathrm{a}}$ \\
\hline
\end{tabular}

*Means in a row with different superscripts are significantly different at $5 \%$ probability by Tukey's test.

According to the Brazilian Standard Quality (BRASIL, 2005), the maximum moisture content for dry pasta is $13 \mathrm{~kg} 100 \mathrm{~kg}^{-1}$. As shown in Table 2, the moisture contents of all the treatments were below the maximum level. The additional water in formulations with MCP did not influence the final moisture content. After $48 \mathrm{~h}$ of drying, all pastas had the same moisture content.

The lipid content is derived basically from the egg, and no difference was observed between the formulations. In the study of Omeire, Umeji and
Obasi (2014), the value of $12.26 \mathrm{~kg} 100 \mathrm{~kg}^{-1}$ was obtained for moisture content in pastas made only with wheat flour. The lipid content reported by Santos et al. (2015) was $2.44 \mathrm{~kg} 100 \mathrm{~kg}^{-1}$, in pasta prepared with refined wheat flour, eggs and salt, which is similar to this study.

For protein, ash, dietary fiber and carbohydrate contents, statistical difference $(\mathrm{P}<0.05)$ was observed and the results are shown in Figure 1, with the regression. 

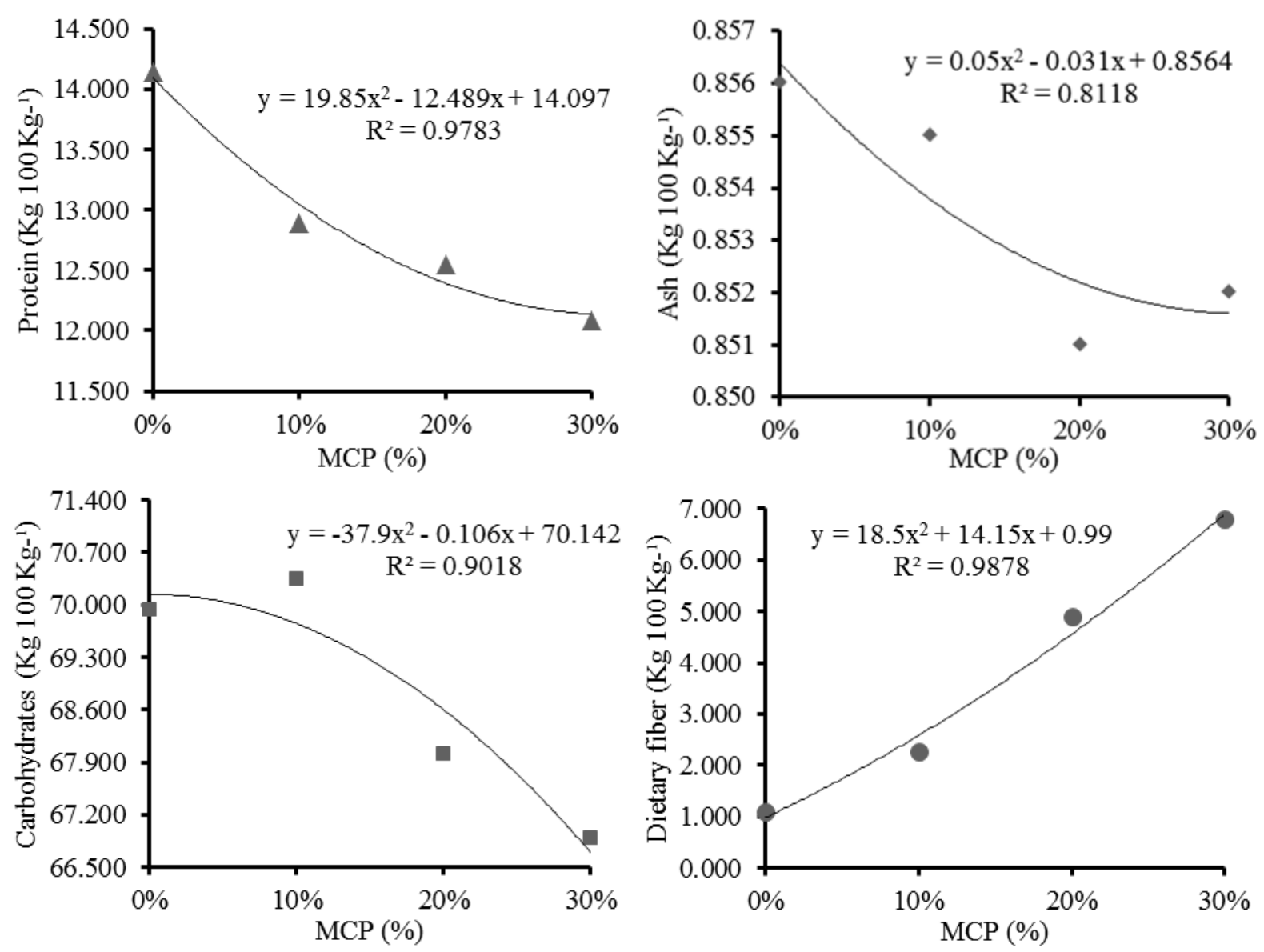

Figure 1. Effect of incorporating MCP on protein, ashes, carbohydrates and dietary fiber contents of spaghetti type pasta.

According to Figure 1, the proteins, ashes and carbohydrates content of the pastas decreased significantly $(\mathrm{p}<0.05)$ with the incorporation of MCP. A regression analysis was conducted, and the correlation coefficients were $0.9782,0.8118$ and 0.9018 for proteins, ashes and carbohydrates, respectively. It should be noted that when MCP was added, there was a reduction in the total percentage of starch (from the wheat flour) in relation to the amount of fiber (mainly observed in the MCP). The increase in fiber content of the samples interrupted the protein and starch matrix (KUMAR; PRABHASANKAR, 2015). It can be observed that even though there were differences between the treatments in relation to the protein content, this reduction was not significant. With regards to the dry weight, with increase in MCP, the other constituents presented a proportional reduction.

In their study, Kumar and Prabhasankar (2015) obtained values of 11.8 and $0.7 \mathrm{~kg}_{100 \mathrm{~kg}^{-1} \text { for }}$ protein and ash content, respectively, for pastas prepared exclusively with wheat flour. Similar values for the carbohydrate content were found by Omeire, Umeji and Obasi (2014), in noodles prepared exclusively with wheat flour $\left(69.44 \mathrm{~kg} 100 \mathrm{~kg}^{-1}\right)$. The reduction in these components, did not affect the caloric value, as demonstrated below.
When the MCP was incorporated, a significant increase in the dietary fiber content was observed (Figure 1); this occurred because the MCP is a raw material rich in fiber. According to the recommendation of RDC no. 54 by the National Agency of Sanitary Surveillance (Anvisa), food which presents more than $3 \mathrm{~kg} 100 \mathrm{~kg}^{-1}$ of dietary fiber, in prepared way, is classified as font of fiber (BRASIL, 2012). So, at 20 and 30\% levels of incorporation of MCP, the pastas presented this classification. The increase in dietary fiber content in products with relevant acceptance and consumption, such as the pasta, may promote beneficial physiologic effects on health, by improving satiety and contributing to the regulation of cholesterol levels (RANINEN et al., 2011).

In relation to the caloric value, there were no statistically significant differences $(p>0.05)$ between the treatments. The values obtained were $361.46 \pm$ $2.15,357.00 \pm 1.86,349.77 \pm 1.62$ and $342.73 \pm 1.65$ $\mathrm{kcal}$ for the $0,10,20$ and $30 \%$ levels, respectively. Rocha et al. (2008) studied the preparation of pasta with wheat flour, eggs and salt, and obtained a caloric value of $351.87 \mathrm{kcal}$.

\section{Cooking test}

The cooking test shows details on pasta behavior 
during cooking by presenting the optimum cooking time, weight gain, volume increase and the loss of solid residues in water. There was no statistically significant difference $(\mathrm{p}>0.05)$ in optimum cooking time, weight gain and volume increase. The result of these parameters is shown in Table 3.

Table 3. Cooking quality of spaghetti type pasta from wheat semolina and micronized corn pericarp.

\begin{tabular}{crrrr}
\hline & \multicolumn{4}{c}{ Spaghetti } \\
\cline { 2 - 5 } Parameters & \multicolumn{1}{c}{ F0 } & F10 & F20 & F30 \\
\hline Optimum cooking & $7.0 \pm 0.5^{\mathrm{a}}$ & $6.5 \pm 0.5^{\mathrm{a}}$ & $6.7 \pm 0.3^{\mathrm{a}}$ & $6.7 \pm 0.3^{\mathrm{a}}$ \\
time (min) & $123.3 \pm 0.6^{\mathrm{a}}$ & $123.6 \pm 0.6^{\mathrm{a}}$ & $124.0 \pm 1.0^{\mathrm{a}}$ & $123.0 \pm 0.0^{\mathrm{a}}$ \\
Weight gain (\%) & $266.6 \pm 1.6^{\mathrm{a}}$ & $266.8 \pm 2.4^{\mathrm{a}}$ & $266.6 \pm 2.8^{\mathrm{a}}$ & $283.3 \pm 3.7^{\mathrm{a}}$ \\
\hline
\end{tabular}

*Means in a row with different superscripts are significantly different, at 5\% probability by Tukey's test.

Spanholi and Oliveira (2009) obtained cooking time of $7 \mathrm{~min}$ for pastas prepared with wheat flour. In a study, Kaur et al. (2012) produced pasta with different cereal brans and obtained cooking time of 5-6 min. These authors proposed that the physical disruption of the gluten matrix by the bran and germ particles provided a path for water absorption in the whole wheat spaghetti, thereby reducing the cooking time.

The weight gain is due to water uptake and indicates the degree of pasta hydration. According to the criteria of Hummel (1966) for weight gain, minimum values of $100 \%$ are characteristic of good quality pasta; therefore, all the samples presented satisfactory water uptake.

An ideal volume increase is found between 200 and $300 \%$, in order for the pasta to be considered of good quality (HUMMEL, 1966). With regards to this classification, all the samples presented good quality (Table 3 ).

In relation to solids loss in cooking water, a statistically significant difference $(\mathrm{p}<0.05)$ was observed. Figure 2 presents the results obtained, a considerable increase can be noted in this parameter with the incorporation of MCP.

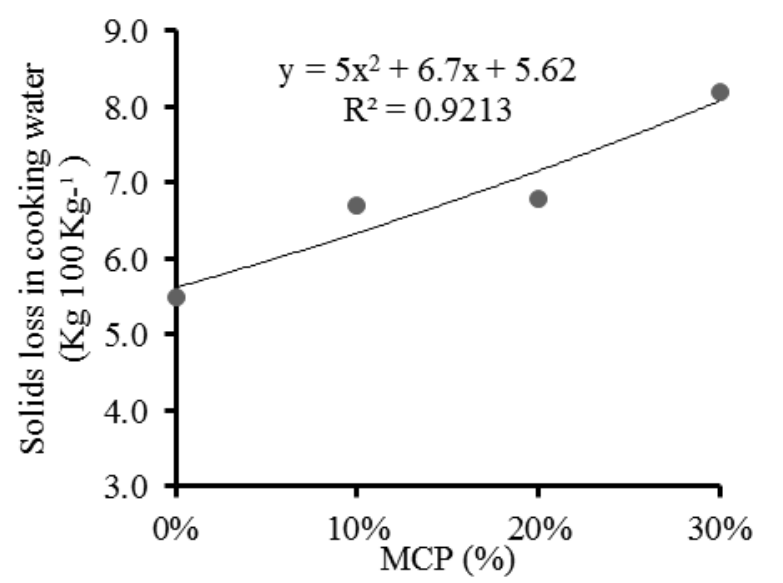

Figure 2. Effect of the incorporation of MCP on the soluble solids content of the cooking water of the spaghetti type pasta.

According to the Figure 2, a positive correlation was observed between MCP incorporation and soluble solid loss $\left(\mathrm{R}^{2}=0.921\right)$. This can be due to leaching of part of the pericarp during cooking. The weakening of gluten structure as a result of MCP addition, promoted the loss of native soluble solids. Niu et al. (2014) reported values ranging from 6.98 to $9.78\left(\mathrm{~kg} 100 \mathrm{~kg}^{-1}\right)$ for solid lost during the cooking of noodles prepared with different particle sizes of wheat flour. Song et al. (2013) observed that the addition of different wheat brans during noodle preparation resulted to a lower soluble solid content in the cooking water.

\section{Color}

Color is the first attribute used by the consumer to evaluate the acceptability of food, thereby presenting importance in the parameters of pasta quality. The color changes in pasta occur mainly during its processing and storage. Color parameters such as luminosity $\left(\mathrm{L}^{*}\right)$ and chromaticity $\left(a^{*}\right.$ and $\left.b^{*}\right)$ are summarized in Table 4 . 
J. R. J. JUNQUEIRA et al.

Table 4. Color parameters of spaghetti type pasta from semolina wheat and micronized corn pericarp.

\begin{tabular}{ccccc}
\hline & \multicolumn{4}{c}{ Spaghetti } \\
\cline { 2 - 5 } Color parameters & F0 & F10 & F20 & F30 \\
\hline $\mathrm{L}^{*}$ & $64.69 \pm 0.79^{\mathrm{a}}$ & $65.05 \pm 0.23^{\mathrm{a}}$ & $65.06 \pm 0.56^{\mathrm{a}}$ & $65.37 \pm 0.18^{\mathrm{a}}$ \\
$\mathrm{a}^{*}$ & $6.56 \pm 0.06^{\mathrm{a}}$ & $6.55 \pm 0.09^{\mathrm{a}}$ & $6.27 \pm 0.10^{\mathrm{ab}}$ & $5.56 \pm 0.04^{\mathrm{b}}$ \\
$\mathrm{b}^{*}$ & $29.93 \pm 0.34^{\mathrm{a}}$ & $29.71 \pm 0.48^{\mathrm{a}}$ & $28.33 \pm 0.22^{\mathrm{a}}$ & $26.03 \pm 0.10^{\mathrm{b}}$ \\
$\Delta \mathrm{E}$ & & 0.24 & 1.63 & 4.04 \\
\hline
\end{tabular}

*Means in a row with different superscripts are significantly different at $5 \%$ probability by Tukey’s test.

As shown in Table 4, there was no significant difference $(p>0.05)$ in luminosity parameter, while there was statistically significant difference $(p<0.05)$ in chromaticity parameters. The higher concentration of MCP incorporation, led to a decrease in the $a^{*}$ and $b^{*}$ attributes, indicating a reduction in the tendency for redness and yellowness, respectively. It occurred due to the higher concentration of fiber, pigments and other structural components, naturally present on external corn layers, as pointed out by Kaminski et al. (2011) in pastas incorporated with wholemeal rye flour. Kumar and Prabhasankar (2015) prepared a control noodle with semolina flour, and obtained values of $68.9 \pm 1.5,1.6 \pm 0.4$ and $20.8 \pm 1.1$ for the color parameters, $\mathrm{L}^{*}, \mathrm{a}^{*}$ and $\mathrm{b}^{*}$, respectively. These authors added rajma bean flour to the pasta, and observed that as the quantity of rajma bean flour increased, the values of $\mathrm{L}^{*}$ and $\mathrm{b}^{*}$ reduced. As shown in Table 4 , the total color difference was higher when the incorporation of MCP increased. The consumers associate darker products with a "rich in fiber food"; the color difference between the treatments was not an undesirable characteristic, as reported by Chillo et al. (2008).

\section{CONCLUSIONS}

Pasta was prepared by MCP incorporation. When up to $30 \%$ of MCP was added to the pasta, a statistically significant difference $(p>0.05)$ was not observed in moisture and lipid contents, caloric value, cooking time, weight gain and volume increase parameters.

A statistically significant difference $(\mathrm{p}<0.05)$ was observed in the protein, ash and carbohydrate contents, and solid lost with the addition of MCP. A reduction in these chemical compositions was influenced by the weakening of protein net, as the bran was incorporated. The dietary fiber content was crescent when the MCP was incorporated, indicating an enrichment of the functional properties of the pasta. The color parameter was slightly affected by the MCP concentration. The inclusion of MCP to the formulation of pasta increased the beneficial properties and showed improvement in pasta quality.

\section{ACKNOWLEDGEMENTS}

The authors gratefully acknowledge CAPES, FAPEMIG, CNPq and EMBRAPA Sorgo e Milho (Unidade Sete Lagoas, Minas Gerais, Brazil) for the financial support.

\section{REFERENCES}

AMERICAN ASSOCIATION OF CEREAL CHEMISTS - AACC. Approved methods of analysis (10th ed.). St. Paul, MN, USA: American Association of Cereal Chemists. 2000.

ASSOCIAÇÃO BRASILEIRA DAS INDÚSTRIAS DE BISCOITOS, MASSAS ALIMENTÍCIAS E PÃES \& BOLOS INDUSTRIALIZADOS ABIMAPI. Estatísticas de consumo per capita de massas alimentícias, São Paulo. Disponível em: $<$ http://www.abimapi.com.br/estatisticamassas.php>. Acesso em: 27 abr. 2016.

ASSOCIATION OF OFFICIAL ANALYTICAL CHEMISTS - AOAC. Official methods of analysis of the AOAC. Washington DC: AOAC Press, 2010.

BERNAUD, F. S. R.; RODRIGUES, T. C. Fibra alimentar: ingestão adequada e efeitos sobre a saúde do metabolismo. Arquivos Brasileiros de Endocrinologia e Metabolismo, São Paulo, v. 57, n. 6, p. 397-405, 2013.

BRASIL. Ministério da Saúde. Agência Nacional de Vigilância Sanitária. Resolução RDC no 54, 12 de novembro de 2012. Regulamento Técnico sobre Informação Nutricional Complementar. Diário Oficial da República Federativa do Brasil, Poder Executivo, Brasília, DF, 2012.

BRASIL. Ministério da Saúde. Agência Nacional de Vigilância Sanitária. Resolução RDC no 263, 22 de setembro de 2005. Regulamento técnico para produtos de cereais, amidos, farinhas e farelos. Diário Oficial da República Federativa do Brasil, Poder Executivo, Brasília, DF, 2005.

CHILLO, S. et al. Quality of spaghetti in base amaranthus whole meal flour added with quinoa, 
broad bean and chick pea. Journal of Food Engineering, Essex, v. 84, n. 1, p. 101-107, 2008.

FERREIRA, D. F. Sisvar: a Guide for its Bootstrap procedures in multiple comparisons. Ciência e Agrotecnologia, Lavras, v. 38, n. 2, p. 109-112, 2014.

GALLEGOS-INFANTE, J. A. et al. Quality of spaghetti pasta containing Mexican common bean flour (Phaseolus vulgaris L.). Food Chemistry, London, v. 119, n. 1, p. 1544-1549, 2010.

HUMMEL, C. H. Macaroni products. London: Food Trade Press, 1966. 287 p.

IBITOYE, W. O. et al. Preliminary Studies of the Chemical Composition and Sensory Properties of Sweet Potato Starch-Wheat Flour Blend Noodles. Nigerian Food Journal, Oshodi, v. 31, n. 2, p. 48$51,2013$.

KAMINSKI, T. A. et al. Atributos nutricionais, tecnológicos e sensoriais de macarrões de centeio. Brazilian Journal of Food Technology, Campinas, v. 14, n. 2, p. 137-144, 2011.

KAUR, G. et al. Functional properties of pasta enriched with variable cereal brans. Journal of Food Science Technology, Amritsar, v. 49, n. 4, p. 467-474, 2012.

KUMAR, S. B.; PRABHASANKAR, P. A study on starch profile of rajma bean (Phaseolus vulgaris) incorporated noodle dough and its functional characteristics. Food Chemistry, London, v. 180, n. 10, p. 124-132, 2015.

NIU, M. et al. Effects of superfine grinding on the quality characteristics of whole-wheat flour and its raw noodle product. Journal of Cereal Science, London, v. 60, n. 2, p. 382-388, 2014.

OMEIRE, G. C.; UMEJI, O. F.; OBASI, N. E. Acceptability of Noodles Produced from Blends of Wheat, Acha and Soybean Composite Flours. Nigerian Food Journal, Oshodi, v. 32, n. 1, p. 31-37, 2014.

OSBORNE, D. R.; VOOGT, P. The analysis of nutrient in foods. London: Academic. n. 47, p. 156-158, 1978.

PAES, M. C. D. Aspectos físicos, químicos e tecnológicos do grão de milho. 1. ed. Sete Lagoas: Embrapa Milho e Sorgo, 2006. 6 p. (Circular técnica, 75).

RANINEN, K. et al. Dietary fiber type reflects physiological functionality: comparison of grain fiber, inulin, and polydextrose. Nutrition Reviews, New York, v. 69, n. 1, p. 9-21, 2011.

ROCHA, D. R. C. et al. Pastas added of ora-pro-nobis (Pereskia aculeata Miller) dehydrated. Alimentos e Nutrição, São Paulo, v. 19, n. 4, p. 459-465, 2008.

SANTOS, J. L. et al. Sensorial and physicochemical qualities of pasta prepared with amaranth. Acta Scientiarum, Maringá, v. 37, n. 1, p. 69-75, 2015.

SIRICHOKWORRAKIT, S.; PHETKHUT, J.; KHOMMOON, A. Effect of partial substitution of wheat flour with riceberry flour on quality of noodles. Procedia - Social and Behavioral Sciences, Kentucky, v. 197, n. 1, p. $1006-1012$, 2015.

SONG, X. et al. Effects of wheat bran with different colors on the qualities of dry noodles. Journal of Cereal Science, London, v. 58, n. 3, p. 400-407, 2013.

SPANHOLI, L.; OLIVEIRA, V. R. Using of passion fruit albedo flour in Passiflora edulis flavicarpa Degener a homemade pasta. Alimentos e Nutrição, São Paulo, v. 20, n. 4, p. 599-603, 2009.

SUN-WATERHOUSE, D.; JIN, D.; WATERHOUSE, G. I. N. Effect of adding elderberry juice concentrate on the quality attributes, polyphenol contents and antioxidant activity of three fiber-enriched pastas. Food Research International, Barking, v. 54, n. 1, p. 781-789, 2013.

WHO. World Health Organization Technical Report Series. Diet, nutrition and the prevention of chronic diseases. 916:i-viii, p. 1-149, 2003. 